\title{
Difficulties and Strategies of Ideological and Political Education of College Students under Background of Internet Public Opinion
}

\author{
Yucui Lu \\ Shandong Laber Vocational and Technical College, Ji'nan, 250022, China
}

Keywords: Internet public opinion. College student. Ideological and political education. Difficulty analysis. Strategy

\begin{abstract}
During development of colleges, invasion of internet public opinion gives rise to certain influences on ideological and political education of college students. How to correctly guide college students to correctly accept internet public opinion becomes an effective approach to perfect ideological and political education of college students so as to serve the life and development of college students. This paper mainly analyzes the effects of internet public opinion on ideological and political education of college students and deeply sets forth countermeasures.
\end{abstract}

\section{Introduction}

In the ear of internet, college students usher in a new era. For college students, internet has become the major channel to get knowledge and information and establish ideological communication and exchange. However, there are numerous information types on internet and information quality is uneven. There is strict regulatory system. Thus, these lead to communication of bad information. Rumors prevail. These lead to great negative effects on college students with immature thoughts. At present, the thoughts of college students are active and sensitive. Thus, they can be easily misled by internet public opinion. Therefore, in the process of ideological and political education of college students, it is required to enhance initiative, foreseeability, pertinence and effectiveness of ideological and political education of college students, build harmonious internet public opinion environment and make information era and ideological development of college students bring out the best in each other.

\section{Connotations of internet public opinion and ideological and political education of college students}

\section{Connotation of internet public opinion}

Internet public opinion is a product combing public opinion and internet. Internet is characterized by openness. Public opinion spreads the opinions and speeches with certain influence and tendency on a focus with the help of internet. Internet public opinion reflects social opinion, social hot issues and difficult problems on internet. It has the features different from traditional public opinions: richness, complexity, diversity, conflict and difficulty in controlling.

\section{Connotation of ideological and political education of college students}

Ideological and political education is a system project. Just as its name implies, ideological and political education refers to ideological education and political education. Ideological and political education of college students takes college students as the objects, regards Marxism-Leninism, Mao Zedong thought and socialist theoretical system with Chinese characteristics as guidance, takes ideal and belief education as the core, regards ideological and moral construction as the foundation and takes patriotism education as the emphasis to educate and guide college students so as to help them establish correct world outlook, outlook on life and values, establish correct political direction, political stand, political attitude and political faith and cultivate socialism constructers and successors with all-round development. 


\section{Influences of internet public opinion on ideological and political education of college students}

\section{Multiple channels influence authority of subject idea}

Traditional education is composed of teachers' oral instruction, blackboard-writing and students' noting. The teaching contents are provided by teachers. Thus, students are led by teachers and are in the passive position. In the 21st century, internet prevails. As an information communication means, internet has such features as global nature, openness, interaction, timeliness, freedom, virtuality and anonymity. Under the condition of anonymity, students can speak out freely and express their opinions or views on social hot issues. Students participate and even become the leaders of some public opinions. This improves students' initiative. Thus, teachers' authority is challenged. Besides, new curriculum reform requires teachers regarding students as the subjects of teaching activities as and teachers playing a guiding role. Thus, teachers' authority is weakened.

\section{Numerous and miscellaneous contents influence effectiveness of subject idea}

Ideological and political education of college students plays a leading role in ideological and political teaching of college students. College students have their own thoughts, ideals and aspirations. Ideological and political education helps them establish correct world outlook, outlook on life and values and establish correct political direction, political stand, political attitude and political faith. Psychology and thoughts of college students are not mature, so they can be easily bewitched. However, due to network openness and content complexity, internet public opinion expresses some opinions on hot issues. So, it is one-sided. Once students' thoughts are led by internet public opinion, it is very hard for teachers to guide them. However, as students' guiders, teachers are responsible for helping students walk out of the wrong region. So, in front of internet public opinion, teachers suffer unprecedented challenges in ideological and political education of students.

\section{Diversified communication techniques influence quality of subject education}

Study and life of college students are closely linked with internet. Campus network provides a convenient platform for communication and information exchange between teachers and students. So, teachers should master new public opinion techniques and utilize all available opportunities and means to guide students. If teachers cannot master new techniques and do not participate in internet public opinion, they cannot know students' conditions well and clearly and solve problems slowly, let alone timely put forward strategies. Thus, ideological and political education of college students cannot reach the requirements. So, it is of great significance to improve teachers' quality.

\section{Difficulties of ideological and political education of college students under the background of internet public opinion}

\section{Social experience of college students is insufficient}

Currently, internet public opinion has become the main information source among college students. The information lacks authenticity. College students lack the ability to judge things. Their thought features include three aspects: firstly, many emergencies are first published on the internet, such as the event of south China tiger and Hanchuan earthquake. College students are sensitive to internet public opinion. They can easily be driven by numerous, disorderly and uncertain network information. Secondly, college students pursue self-assertion and prefer to control the right of speech of public opinion. They often have great vanity and like self-expression. They participate in internet public opinion by all means. They please themselves through influencing others. Finally, physiological age of college students is in the special period, so they can be easily utilized by manipulators of internet public opinion. They have no strong ability to know right from wrong. They can lose themselves easily ideologically, with large emotional fluctuations. There are many blind conformity phenomena.

\section{Imperfect internet media mechanism}

Imperfect internet media mechanism is mainly reflected in three aspects: firstly, internet is a virtual society. Netizens do not make their identities public in the internet world, so when netizens publish some speeches, they do not worry they will be investigated. The anonymity of internet public 
opinion weakens ideological and political education of college students. They can freely give vent to their dissatisfactions, with free speeches. Secondly, openness is the largest advantage of internet. College students can post information on network at will. The contents are also various. It is very difficulty to control guidance of public opinion. Ideological educators of college students have no the advantage of information resources. Thus, it is very hard to control internet public opinion. Thirdly, large quantities of information which is not verified mislead many people. Those posting such information are called "internet marketers". Internet marketers often make some untrue internet public opinions. College students can easily follow suit in front of untrue e internet public opinions and sometimes are utilized. Ideological education pressure is huge under internet.

\section{Lack of correct ideological education guidance}

Under the background of internet public opinion, ideological and political education of college students is weak, which is mainly reflected in the following: firstly, when China's colleges and universities face emergencies, there is lack of emergency mechanism. They fail to disclose the truth immediately and even adopt the methods of "stopping” and "covering”. Thus, large negative effects appear. Ideological and political education of college students thus becomes very passive. Secondly, for the hot issues, several possible public opinions will occur in internet. There is no special management and analysis organization for internet public opinion. Colleges and universities are often caught in the passive situation. Rumors exist everywhere. Finally, the guidance of ideological and political education of college students becomes very passive. Thirdly, cognition of current internet public opinion is seriously insufficient. Internet public opinion has strong extension, seepage force and unique interactivity. Such characteristic makes us lack powerful self-confidence when infusing our comprehension and judgment to students.

\section{Problems and contradictions in the period of social transition}

Since the reform and opening-up, China's economy and society have gained remarkable achievements. However, many new problems occur, such as the difficulty in getting medical treatment and buying houses. Meanwhile, with unavoidability of natural hazards, great changes have taken place for people's ideology. Thus, deviations will occur in ideological and political education of college students. Interest prevails in modern society. The competitions are very fierce. The objectives of college students are also every-changing. The life, identity and status of college students in market economy cannot be ensured. Dissatisfaction of college students with the society is utilized by a few hostiles who spread some bad information on the internet to deceive people. This gives rise to large obstacles to China's socialist modernization.

\section{Countermeasures of ideological and political education of college students under the background of internet public opinion}

\section{To improve media accomplishment of college students}

Media accomplishment of college students means college students should have certain selective ability and comprehensive ability, boldly query and evaluate internet public opinion, instead of overall affirmation or total refusal when facing various kinds of information of internet public opinion. They should have creation and production ability to think and judge the information form internet public opinion so as to own their own thoughts. Internet era is different from the era of journalists. Apart from professional journalists, anyone can participate in internet, far exceeding the quantity and capacity of traditional media. However, the quality of event reports is uneven. It is hard to distinguish true and false information. Thus, it is very necessary for college students to improve their media accomplishment. In particular, during ideological and political education of college students, there should be positive guidance in allusion to campus network media. Colorful online education should be implemented for students and certain services should be provided for students. Meanwhile, rule-of-law education and moral education should be promoted so as to make college students have correct and scientific cognition, really use internet and provide help for students' development. 


\section{To control guidance approach and technology of internet public opinion}

Current college students bid farewell to single and deficient thoughts. They advocate individuality and display self-confidence. Internet has become an essential part of their life. It thus can be seen that if guidance of internet public opinion is appropriate, ideological and political education of college students can be correctly guided to help them correct their cognitive defect. This should start from campus network to establish internet mainstream and serve as "gate-keepers" of internet public opinion. It is required to enhance study of professional knowledge and the ability to deal with internet information according to the development law of internet public opinion in allusion to psychological characteristics of college students. Besides, it is required to strengthen monitoring and filtration of network technique, detect and track properly, make prevention and control system of network technique well, correctly guide and control internet public opinion so as to create good space for ideological and political education of college students.

To guide internet public opinion with ideological and political education of college students

The popularity of internet gradually becomes a main factor influencing ideological and political education of college students. Meanwhile, it provides an effective approach to know ideological changes, individual demands and value orientation of college students and meanwhile supplies important materials and basis for ideological and political education of college students. On the one hand, teachers should reinforce ideological and political education of college students, know Chinese and foreign situations as well as hot issues and master cognition and features of students for social hot issues in order to set up correct direction for internet public opinion. On the other hand, teachers should perfect feedback and handling approaches of internet public opinion, arrange "observers" for problems and do "ideological fire control" work well in order to improve ideological and political quality of students, served the development of college students and make internet public opinion really become "the accelerator" to improve students' quality.

\section{To deal with contradictions in the period of social transition}

At present, China is in transitional period when economic and social contradictions stand out. These contradictions are unavoidable, but can be controlled. Regardless of social welfare, gap between the rich and the poor, vulnerable group and employment corruption, these internet public opinions cannot be solved with one sentence of the government. Thus, the government should solve them fundamentally and establish public trust of policy formulation, execution and inspection organizations. The government should adopt positive attitude to treat contradictions, weaken contradictions to the largest extent, acquire trust and drive ideological and political education of college students by use of general environment. The government should advertise, unify thought, gather public feeling, promote development, listen attentively, make the attitude correct, timely know and understand popular will, face "opinions" rationally, treat public opinions fairly, enhance information transparency, respect peasants' right to know, participation right and supervision right, build frank and forthright image, create sunny public opinion environment for college students and lay foundation for ideological and political education of college students.

\section{Conclusions}

College students as constructers and successors to construct the motherland and revitalize the Chinese nation shoulder great historical mission. Chinese Communist Party has made great efforts in ideological and political education and thoroughly analyzed the effects of internet public opinion on the thoughts of college students. Besides, we actively encounter various problems. As long as we effectively utilize internet, we can cope with challenges any time, explore a development way suitable for fusing internet public opinion and ideological and political education, eliminate disadvantages and keep the advantages so as to make internet public opinion become a new approach for ideological and political education of college students. 


\section{References}

[1] Propaganda and Education Bureau of Propaganda Department of the CPC. Opinions of The State Council on further enhancing and improving ideological and political education of college students, Beijing: China Renmin University Press, 2005

[2] Xu Jianjun: Theories and methods of network ideological and political education of college students, Beijing: People's Publishing House, 2010.

[3] Wang Bin: Study on ideological and political education by college counselors under internet environment [D], Fu Zhou, Fujian Normal University, 2010

[4] Guo Zhixin: On effects of internet public opinion on values of college students, Journal of Liaoning Institute of Science and Technology, 2007.3

[5] Wang Lingling: Features and guidance of internet public opinion among college students, Ideological \& Theoretical Education, 2006.3

[6] Li Yuquan, Lu Lili: Efficiency and realization of internet public opinion in ideological and political education in colleges, Editorial Department of Ideological and Political Education Research, 2010.3 